\title{
Evaluation of honeys and bee products quality based on their mineral composition using multivariate techniques
}

\author{
Malgorzata Grembecka $\cdot$ Piotr Szefer
}

Received: 25 June 2011 / Accepted: 13 August 2012 /Published online: 29 August 2012

(C) The Author(s) 2012. This article is published with open access at Springerlink.com

\begin{abstract}
The aim of this investigation was to estimate honeys and bee products quality in view of their mineral composition using multivariate techniques. Fourteen elements $(\mathrm{Ca}, \mathrm{Mg}, \mathrm{K}, \mathrm{Na}, \mathrm{P}, \mathrm{Co}, \mathrm{Mn}, \mathrm{Fe}$, $\mathrm{Cr}, \mathrm{Ni}, \mathrm{Zn}, \mathrm{Cu}, \mathrm{Cd}$, and $\mathrm{Pb}$ ) were determined in 66 honeys and bee products from different places of Poland and Europe and various botanical origins. The total metals contents were analyzed by flame atomic absorption spectrometry using deuteriumbackground correction after wet digestion with nitric acid in an automatic microwave digestion system. Phosphorus was determined in the form of phosphomolybdate by a spectrophotometric method. Reliability of the procedure was checked by analysis of the certified reference materials tea (NCS DC 73351) and cabbage (IAEA-359). The analytical data indicated a good level of quality of honeys, especially with regard to the concentration of toxic trace elements, such as $\mathrm{Cd}$ and $\mathrm{Pb}$. Results were submitted to multivariate analysis, including such techniques as factor and cluster analyses in order to evaluate the existence of data patterns and the possibility of classification of honeys from different botanical origins according to their mineral content. The nine metals determined were considered as chemical descriptors of
\end{abstract}

M. Grembecka $(\bowtie) \cdot$ P. Szefer Department of Food Sciences, Medical University of Gdańsk,

Al. Gen. J. Hallera 107,

80-416 Gdansk, Poland

e-mail: mgrembecka@gumed.edu.pl each sample. There was a significant influence of the botanical and geographical provenance as well as technological processing on the elemental composition of honeys.

Keywords Honeys · Metals · AAS · ANOVA · Factor analysis $\cdot$ Cluster analysis

\section{Introduction}

Honey is the food product that the domesticated bees (Apis mellifera L.) produce and transform from the nectar of flowers or from the sugar secretions from the leaves of arboreal essence. Besides being healthy and easy to digest, this natural product is full of carbohydrates, vitamins, minerals, and enzymes (Alvarez-Suarez et al. 2010; Hernández et al. 2005). Other bee product, propolis, is actually a complex mixture of resins and other substances that honeybees use to seal the hive and make it safe from bacteria and other microorganisms (Xu et al. 2009). Honeybees make propolis by combining plant resins with their own secretions. Its composition varies considerably from region to region as well as along with the vegetation. Similarly to honey, it is also believed to promote heart health, strengthen the immune system, and reduce the chances of viral diseases (Xu et al. 2009).

Honeys can be found in all types of colors and flavors from nearly colorless to dark brown, and its flavor varies from delectably mild to distinctively bold 
since both the flavor and color are directly influenced by the type of nectar gathered by the bees from various floral sources. Usually a lighter color will indicate a milder flavor, while darker honey is customarily more robust and contains more minerals. Varietal honey is rarely $100 \%$ of any one type of flower nectar but a blend with a predominance of one type of flower forage. In addition to being a natural nutritive sweetener, research also indicates that honey's unique composition makes it useful as an antimicrobial agent and antioxidant. Honey also reduces skin inflammation, edema, and exudation as well as promotes wound healing, diminishes scar size, and stimulates tissue regeneration (Alvarez-Suarez et al. 2010). It has been also found that it ameliorates cardiovascular risk factors as well as being a potent inhibitor of Helicobacter pylori. What is more, honeys express antimutagenic activity against bladder cancer and mammary carcinoma (Alvarez-Suarez et al. 2010). The health benefits of honey depend on its quality that is strongly associated with its chemical composition and floral origin.

Food quality requires the control of nutritional value, sensorial properties, authenticity, and safety. Honeys come from a wide range of geographical areas and may have varied chemical and organoleptic properties. Therefore, it is very important to have methods to characterize different honey varieties. Their common characteristics is moisture content below $20 \%$, a reducing sugar content of $60-65 \%$, and a bulk sucrose content of 5-10\% (Alvarez-Suarez et al. 2010; Hernández et al. 2005). However, it is possible to find parameters that could differentiate honeys and one of such criteria is their metal content (Hernandez et al. 2005; Tuzen et al. 2007). Metals concentration ranges from about $0.04 \%$ in light color honeys to $0.2 \%$ in some dark honeys, and protein content of honey is usually lower than $0.5 \%$ (Alvarez-Suarez et al. 2010; Fernàndez-Torres et al. 2005).

Advanced statistical chemometric techniques are very effective in analytical evaluation of food quality. Based on the mineral composition data, it is possible to record the influence of elements on the distribution of particular object samples and classify food products according to their country of origin, type, and genetic classification (Szefer 2007). Several authors have applied chemometrical procedures on elemental composition data in order to classify honeys in view of their botanical and geographical provenance (Chudzinska and Baralkiewicz 2010; Devillers et al. 2002;
Fernàndez-Torres et al. 2005; Hernández et al. 2005; Latorre et al. 1999; Pisani et al. 2008).

The aim of the present investigations was to analyze and compare concentrations of macro- and microelements and toxic metals in 66 brands of commercially available honeys and bee products from different regions of Poland and Italy (Table 1) obtained from the local market in Poland. Moreover, we wanted to define honey quality with regard to several toxic elements such as lead and cadmium. Due to relatively low cost and quite good analytical performance, flame atomic absorption spectrometry (FAAS) has been used for analyses. For the classification and discrimination between the different types of honey, factor and cluster analyses were carried out. Results of the analyses highlight the potential of the use of elemental composition for the discrimination and classification of honey and bee products in view of their botanical provenance, type, and level of technological processing.

\section{Materials and methods}

Honey and bee products samples

Honeys samples to be analyzed were purchased from the local market in Gdańsk (Poland) as well as from beekeeper's shops throughout the country in 2004 and 2005. The samples represented the most common types of honey readily available to consumers in Poland. The honeys analyzed were classified according to the producer statement on the label. Products included natural honeys of different botanical origins (acacia, buckwheat, apple, chestnut, lime, dandelion, orange, rape, honeydew, multifloral, and heather) as well as syrup-feed honeys, honeys with natural additives such as chokeberry, cinnamon, pollen and propolis, and other bee products, including bee pollen and propolis. There were also analyzed samples of inverted sugar syrup which is commercialized in Poland under the name artificial honey. It has an appearance similar to honey and is often used as a substitute for people who do not eat honey. It consists of glucose and fructose syrup produced by inversion, which has been blended with the original sucrose syrup in a proportion that creates a thick mixture which does not crystallize. In total, 66 products (198 subsamples) were analyzed in triplicate for 
Table 1 Characteristics of the analyzed products

\begin{tabular}{|c|c|c|c|}
\hline Product & Details & Product & Details \\
\hline \multicolumn{4}{|l|}{ Honeys } \\
\hline Acacia honey & Certified origin, North Eastern Poland & Honeydew honey & Certified origin, South Eastern Poland \\
\hline Acacia honey & Certified origin, North Eastern Poland & Multifloral honey & Certified origin, Northern Poland \\
\hline Acacia honey & Certified origin, central Poland & Multifloral honey & Certified origin, central Poland \\
\hline Acacia honey & Certified origin, South Eastern Poland & Multifloral honey & Certified origin, central Poland \\
\hline Acacia honey & Certified origin, South Eastern Poland & Multifloral honey & Certified origin, North Eastern Poland \\
\hline Eucalyptus honey & Certified origin, Italy & Multifloral honey & Certified origin, central Poland \\
\hline Buckwheat honey & Certified origin, South Eastern Poland & Multifloral honey & Certified origin, central Poland \\
\hline Buckwheat honey & Certified origin, central Poland & Multifloral honey & Certified origin, Italy \\
\hline Buckwheat honey & Certified origin, North Eastern Poland & Heather honey & Certified origin, North Eastern Poland \\
\hline Buckwheat honey & Certified origin, central Poland & Heather honey & Certified origin, Southern Poland \\
\hline Buckwheat honey & Certified origin, South Eastern Poland & Artificial honey & Produced in Poland \\
\hline Buckwheat honey & Certified origin, central Poland & Artificial honey & Produced in Poland \\
\hline Apple honey & Certified origin, Italy & Syrup-feed honeys & \\
\hline Chestnut honey & Certified origin, Italy & Aloe syrup-feed honey & Produced in Poland \\
\hline Lime honey & Certified origin, South Eastern Poland & Chokeberry syrup-feed honey & Produced in Poland \\
\hline Lime honey & Certified origin, central Poland & Crataegus syrup-feed honey & Produced in Poland \\
\hline Lime honey & Certified origin, Southern Poland & Stinging nettle syrup-feed honey & Produced in Poland \\
\hline Lime honey & Certified origin, central Poland & Pine syrup-feed honey & Produced in Poland \\
\hline Lime honey & Certified origin, North Eastern Poland & Syrup-feed honey & Produced in Poland \\
\hline Lime honey & Certified origin, central Poland & Honeys with natural additives & \\
\hline Lime honey & Certified origin, North Eastern Poland & Bee honey with chokeberry & Produced in Poland \\
\hline Dandelion honey & Certified origin, North Eastern Poland & Bee honey with cinnamon & Produced in Poland \\
\hline Orange honey & Certified origin, Italy & Bee honey with pollen & Produced in Poland \\
\hline Rape honey & Certified origin, Northern Poland & Royal jelly in honey & Produced in Poland \\
\hline Rape honey & Certified origin, central Poland & Propolis in honey & Produced in Poland \\
\hline Rape honey & Certified origin, central Poland & Bee products & \\
\hline Rape honey & Certified origin, Northern Poland & Propolis & Produced in Poland \\
\hline Rape honey & Certified origin, central Poland & Propolis & Produced in Poland \\
\hline Honeydew honey & Certified origin, South Eastern Poland & Bee pollen & Produced in Poland \\
\hline Honeydew honey & Certified origin, North Eastern Poland & Bee pollen & Produced in Poland \\
\hline Honeydew honey & Certified origin, central Poland & Bee pollen & Produced in Poland \\
\hline Honeydew honey & Certified origin, North Eastern Poland & Bee pollen & Produced in Poland \\
\hline Honeydew honey & Certified origin, North Eastern Poland & & \\
\hline
\end{tabular}

macroelements $(\mathrm{Mg}, \mathrm{Ca}, \mathrm{K}, \mathrm{Na}$, and $\mathrm{P})$, microelements ( $\mathrm{Zn}, \mathrm{Cu}, \mathrm{Fe}, \mathrm{Cr}, \mathrm{Co}, \mathrm{Ni}$, and $\mathrm{Mn}$ ), and toxic elements $(\mathrm{Pb}$ and $\mathrm{Cd})$. All analyzed products are characterized in Table 1.

\section{Sample preparation and analysis}

Three replicates of $1-\mathrm{g}( \pm 0.0001 \mathrm{~g})$ samples were treated with $9 \mathrm{ml} 65 \% \mathrm{HNO}_{3}$ (Suprapur ${ }^{\circledR}$ Merck) and then digested in an automatic microwave digestion system (MLS 1200M) according to the following steps: I, $250 \mathrm{~W}, 48 \mathrm{~s}$; II, $0 \mathrm{~W}, 48 \mathrm{~s}$; III, $250 \mathrm{~W}, 6 \min 24 \mathrm{~s}$; IV, $400 \mathrm{~W}, 4 \mathrm{~min} ; \mathrm{V}, 650 \mathrm{~W}, 4 \mathrm{~min}$. The steps are described in detail in the operation manual. Every microwave digestion cycle consisted of five food samples and one blank sample ( $9 \mathrm{ml} 65 \% \mathrm{HNO}_{3}$ ). After digestion, the vessels were cooled at room temperature. Every digested sample was dissolved up to $10 \mathrm{ml}$ with deionized water. 
The concentrations of elements $(\mathrm{Mg}, \mathrm{Ca}, \mathrm{K}, \mathrm{Na}, \mathrm{Zn}$, $\mathrm{Cu}, \mathrm{Fe}, \mathrm{Cr}, \mathrm{Co}, \mathrm{Ni}, \mathrm{Mn}, \mathrm{Pb}$, and $\mathrm{Cd}$ ) were determined in an air-acetylene flame by AAS method using deuterium-background correction. A Philips PU-9100 model atomic absorption spectrometer was used for metal analyses. The FAAS conditions are described in the operation manual. In the case of $\mathrm{Na}$ and $\mathrm{K}$ determinations, Cs was added to samples and standards as an ionization buffer at a concentration of $0.2 \% \mathrm{w} / \mathrm{v}$, and in the case of $\mathrm{Ca}$ and $\mathrm{Mg}$ measurements, $\mathrm{La}$ was used as a releasing agent at a concentration of $0.4 \% \mathrm{w} /$ v. Phosphorus was determined in the form of phosphomolybdate by spectrophotometric method (Official Methods of Analysis of AOAC International 2002).

Nickel, $\mathrm{Co}, \mathrm{Cr}, \mathrm{Pb}$, and $\mathrm{Cd}$ concentrations in the samples analyzed were under the detection limits of the method applied, i.e., 0.02, 0.01, 0.02, 0.01, and $0.003 \mathrm{mg} 100 \mathrm{~g}^{-1}$. The detection limit was established according to Konieczka and Namieśnik (2009), i.e., $\mathrm{LD}=$ blank mean $+3 \mathrm{SD}$. The reliability of the method was tested with certified standard reference materials including tea (NCS DC 73351) and cabbage (IAEA359). The recoveries obtained for the reference materials varied between $84.5 \%$ and $103 \%$, and precisions were $0.13-13 \%$.

Estimation of recommended dietary intake and provisional tolerable monthly intake

The daily mineral intake (in percent) through consumption of $25 \mathrm{~g}$ (one tablespoon) of the products analyzed was calculated as $\mathrm{DMI}=C \times 100 / \mathrm{RDA}$, where $C$ is element concentration (in milligrams) in $25 \mathrm{~g}$ of product and RDA is according to the National Polish Food and Nutrition Institute (Jarosz and BułhakJachymczyk 2008) or American data (Dietary Reference Intakes 2004).

In accordance with recommendation of $\mathrm{FAO} / \mathrm{WHO}$ (WHO 2010a, b), a provisional tolerable monthly intake (PTMI) for Cd amounted to $25 \mu \mathrm{g} / \mathrm{kg}$ of body weight for adult, i.e., $490 \mu \mathrm{g}$ monthly for $70 \mathrm{~kg}$ person. At the 73rd FAO/WHO Meeting (WHO 2010b), the Committee concluded that the PTWI for $\mathrm{Pb}$ could no longer be considered health protective and withdrew it. Furthermore, as the dose-response analyses did not provide any indication of a threshold for the key adverse effects of $\mathrm{Pb}$, the Committee concluded that it was not possible to establish a new PTWI that would be health protective (WHO 2010b).

\section{Statistics}

Spearman's rank correlation analysis, ANOVA Kruskal-Wallis test, factor analysis (FA), and cluster analysis (CA) of the data obtained were performed using STATISTICA 8.0 for Windows (Copyright $^{\odot}$ StatSoft, Inc. 1984-2007). Before the chemometric analysis, the selected variables were tested for normality. In all cases, they did not follow the normal distribution according to Shapiro-Wilk and the Kolmogorov-Smirnov tests (Brereton 2003; Szefer 2007). Therefore, nonparametric procedures were adapted in our analyses. Prior the chemometric processing, the data matrix were autoscaled. FA was performed on raw data sets concerning honeys and bee products samples. The data matrix was established using the elements as columns and analyzed products as rows. Each product's arithmetic mean value of three subsamples was taken into consideration; therefore, 38 natural honeys and 50 natural, syrup-feed, artificial, and with natural additives honeys accounted for the final data matrix. Elements such as $\mathrm{Pb}, \mathrm{Cd}, \mathrm{Cr}, \mathrm{Ni}$, and $\mathrm{Co}$ had to be eliminated from the data set because of their too low levels; therefore, nine loadings $(\mathrm{Ca}, \mathrm{Mg}$, $\mathrm{Na}, \mathrm{K}, \mathrm{P}, \mathrm{Zn}, \mathrm{Cu}, \mathrm{Fe}$, and $\mathrm{Mn}$ ) constituted the ultimate data matrix. All elements proved to have great contribution to samples differentiation (Tables 2 and 3 ). The cut-off loading value to determine which elements will be used at the clustering stage was set at the level $>0.70$. CA, similarly to FA, was also performed on raw data sets concerning honeys and bee products samples.

Table 2 Factor loadings for elements analyzed in honeys of different botanical families

\begin{tabular}{llr}
\hline & Factor 1 & \multicolumn{1}{c}{ Factor 2 } \\
\hline $\mathrm{Ca}$ & -0.193354 & 0.330832 \\
$\mathrm{Mg}$ & -0.707836 & -0.077388 \\
$\mathrm{Na}$ & -0.273910 & 0.763634 \\
$\mathrm{~K}$ & -0.845422 & 0.295266 \\
$\mathrm{P}$ & -0.720763 & -0.029373 \\
$\mathrm{Zn}$ & 0.000804 & 0.403728 \\
$\mathrm{Cu}$ & -0.872018 & -0.345827 \\
$\mathrm{Fe}$ & -0.110214 & -0.584865 \\
$\mathrm{Mn}$ & -0.770736 & -0.104390 \\
\hline
\end{tabular}


Table 3 Factor loadings for elements analyzed in different types of honeys

\begin{tabular}{lrr}
\hline & \multicolumn{1}{l}{ Factor 1 } & \multicolumn{1}{l}{ Factor 2 } \\
\hline $\mathrm{Ca}$ & 0.014845 & 0.551394 \\
$\mathrm{Mg}$ & -0.618603 & 0.165681 \\
$\mathrm{Na}$ & 0.161171 & 0.677685 \\
$\mathrm{~K}$ & -0.841946 & 0.183504 \\
$\mathrm{P}$ & -0.767338 & 0.041556 \\
$\mathrm{Zn}$ & -0.161139 & -0.218379 \\
$\mathrm{Cu}$ & -0.876076 & -0.056267 \\
$\mathrm{Fe}$ & -0.201850 & -0.623420 \\
$\mathrm{Mn}$ & -0.780438 & 0.049780 \\
\hline
\end{tabular}

The best results of CA analysis were obtained by applying the Ward method as a way of calculating of cluster distances, as well as Euclidean distance as a measure of distance between analyzed samples.

\section{Results and discussion}

Element concentrations in honeys

Data of the elements analyzed in honeys and bee products are listed in Tables 4 and 5. The minerals concentrations in the samples are characterized by arithmetic mean value, the corresponding standard deviation (SD), and ranges for wet weight basis.

The macroelements concentrations in the analyzed samples were quite varied, which might result from diverse geographical origin of samples, with the highest values for $\mathrm{K}$ and $\mathrm{P}$ (Table 4). Concentration ranges of $\mathrm{K}$ in $100 \mathrm{~g}$ of honeys and bee products samples were as follows: 16.6-73.6 $\mathrm{mg}$ (honeys), 11.1$31.7 \mathrm{mg}$ (syrup-feed honeys), 17.9-54.2 mg (honeys with natural additives), and 49.9-70.0 mg (bee products). Latorre et al. (1999) reported almost four times higher $\mathrm{K}$ levels in Galician and sesame honeys, while Al-Khalifa and Al-Arify (1999), Terrab et al. (2003), and Yilmaz and Yavuz (1999) lower ones. Chudzinska and Baralkiewicz (2010) determined much higher K concentrations in honeydew and buckwheat honeys, i.e., 264 and $69.5 \mathrm{mg} 100 \mathrm{~g}^{-1}$, respectively. Also, Siena honeys contained high concentrations of K, i.e., 14.7-413.6 mg $100 \mathrm{~g}^{-1}$ (Pisani et al. 2008). Spanish honeys contained between 63.9 and $184.5 \mathrm{mgK}$ in $100 \mathrm{~g}$ (Fernàndez-Torres et al. 2005).
P concentration ranged from 3.57 to $69.6 \mathrm{mg}$ in honeys, 7.14-29.7 $\mathrm{mg}$ in syrup-feed honeys, 23.2$108 \mathrm{mg}$ in honeys with natural additives, and 573$659 \mathrm{mg} 100 \mathrm{~g}^{-1}$ in bee products (Table 4). Much lower values, in comparison to our results, were reported for P by Kunachowicz et al. (2005), Souci et al. (2002), and Terrab et al. (2004). Fernàndez-Torres et al. (2005) determined $\mathrm{P}$ in Spanish honeys in the range of 6.38 and $14.3 \mathrm{mg} \mathrm{P} 100 \mathrm{~g}^{-1}$.

The highest $\mathrm{Ca}$ level was obtained for bee pollen and

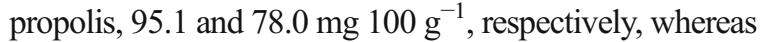
the lowest was for syrup-feed honey, i.e., $2.25 \mathrm{mg} 100 \mathrm{~g}^{-1}$. According to Devillers et al. (2002), average Ca concentration in natural honeys amounted to $2.29 \mathrm{mg} 100 \mathrm{~g}^{-1}$, whereas Capar and Cunningham (2000), Kanoniuk et al. (2004), Nanda et al. (2003), and Yilmaz and Yavuz (1999) determined this macroelement in the range of 4.1 and $5.88 \mathrm{mg} 100 \mathrm{~g}^{-1}$. Terrab et al. (2004) reported much higher values for $\mathrm{Ca}$. According to Fernàndez-Torres et al. (2005), Ca concentration in Spanish honeys varied

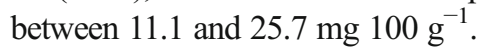

The highest $\mathrm{Mg}$ concentration was determined in bee pollen, i.e., $77.4 \mathrm{mg} 100 \mathrm{~g}^{-1}$. Its levels in all other types of the analyzed samples ranged from 0.28 to $25.3 \mathrm{mg} 100 \mathrm{~g}^{-1}$ (Table 4). Kunachowicz et al. (2005) determined comparable Mg levels, whereas Rashed and Soltan (2004) reported much higher values for clover honeys, i.e., $24.4 \mathrm{mg} 100 \mathrm{~g}^{-1}$.

Among natural honeys, the richest source of $\mathrm{Na}$ was dandelion $\left(7.41 \mathrm{mg} 100 \mathrm{~g}^{-1}\right)$, whereas the lowest concentration of this metal was determined in chestnut honey $\left(0.78 \mathrm{mg} 100 \mathrm{~g}^{-1}\right)$. Syrup-feed honeys and honeys with natural additives characterized by $\mathrm{Na}$ levels in the range of 0.59 and $2.43 \mathrm{mg} 100 \mathrm{~g}^{-1}$ (Table 4). Comparable results for $\mathrm{Na}$ are reported by Capar and Cunningham (2000), Conti (2000), Latorre et al. (1999) as well as Souci et al. (2002). However, Latorre et al. (1999), Nanda et al. (2003), Terrab et al. (2004), and Yilmaz and Yavuz (1999) found higher concentrations in natural bee honeys.

Zinc concentration in the honeys samples analyzed

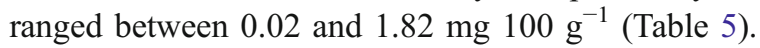
The average concentrations of $\mathrm{Zn}$ were the highest in bee products such as propolis $(4.33 \mathrm{mg}$ $100 \mathrm{~g}^{-1}$ ) and bee pollen (2.90 mg $100 \mathrm{~g}^{-1}$ ), while the lowest were in acacia honey with almonds (0.02 mg $\left.100 \mathrm{~g}^{-1}\right)$. According to Souci et al. (2002) and Chudzinska and Baralkiewicz (2010), average $\mathrm{Zn}$ level in honeys amounted to 0.35 and 


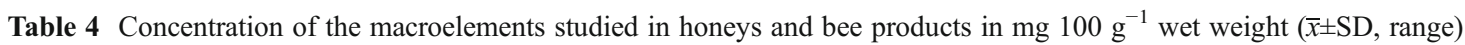

\begin{tabular}{|c|c|c|c|c|c|c|c|}
\hline Product & $N$ & $n$ & $\mathrm{Ca}$ & $\mathrm{Mg}$ & $\mathrm{Na}$ & $\mathrm{K}$ & $\mathrm{P}$ \\
\hline \multicolumn{8}{|l|}{ Honeys } \\
\hline \multirow[t]{2}{*}{ Acacia honeys } & 5 & 15 & $4.88 \pm 1.68$ & $1.01 \pm 0.41$ & $1.30 \pm 1.67$ & $16.6 \pm 2.86$ & $14.0 \pm 9.91$ \\
\hline & & & $2.86-6.92$ & $0.65-1.4$ & $0.38-4.28$ & $12.7-19.6$ & $7.14-28.6$ \\
\hline \multirow[t]{2}{*}{ Eucalyptus honey } & 1 & 3 & $5.28 \pm 0.50$ & $1.76 \pm 0.21$ & $5.63 \pm 0.07$ & $45.3 \pm 1.33$ & $57.1 \pm 3.61$ \\
\hline & & & $4.81-5.80$ & $1.61-1.91$ & $5.58-5.68$ & $44.5-46.9$ & $53.5-60.7$ \\
\hline \multirow[t]{2}{*}{ Buckwheat honeys } & 6 & 19 & $3.37 \pm 1.24$ & $1.66 \pm 0.38$ & $0.98 \pm 0.21$ & $32.2 . \pm 9.55$ & $69.6 \pm 18.2$ \\
\hline & & & $1.95-5.50$ & $1.05-2.00$ & $0.57-1.15$ & $19.7-43.7$ & $47.6-92.7$ \\
\hline \multirow[t]{2}{*}{ Apple honey } & 1 & 3 & $5.70 \pm 0.43$ & $14.5 \pm 0.61$ & $2.39 \pm 0.01$ & $73.6 \pm 0.58$ & $48.8 \pm 2.05$ \\
\hline & & & $5.40-6.01$ & $14.0-15.2$ & $2.38-2.40$ & $72.9-74.1$ & $46.5-50.1$ \\
\hline \multirow[t]{2}{*}{ Chestnut honey } & 1 & 3 & $5.50 \pm 0.13$ & $4.93 \pm 0.05$ & $0.78 \pm 0.04$ & $70.9 \pm 0.46$ & $14.3 \pm 0.01$ \\
\hline & & & $5.40-5.59$ & $4.89-4.99$ & $0.75-0.82$ & $70.6-71.4$ & $14.3-14.3$ \\
\hline \multirow[t]{2}{*}{ Lime honeys } & 7 & 21 & $3.97 \pm 0.84$ & $1.60 \pm 0.63$ & $1.89 \pm 1.38$ & $39.3 \pm 12.6$ & $13.0 \pm 7.48$ \\
\hline & & & $2.55-4.80$ & $0.73-2.70$ & $0.92-4.76$ & $22.4-52.8$ & $3.58-23.8$ \\
\hline \multirow[t]{2}{*}{ Dandelion honey } & 1 & 3 & $6.11 \pm 0.29$ & $0.90 \pm 0.001$ & $7.41 \pm 0.23$ & $51.1 \pm 1.62$ & $7.15 \pm 0.01$ \\
\hline & & & $5.90-6.31$ & $0.90-0.90$ & $7.25-7.57$ & $49.2-52.1$ & $7.14-7.16$ \\
\hline \multirow[t]{2}{*}{ Orange honey } & 1 & 3 & $2.76 \pm 0.07$ & $0.55 \pm 0.07$ & $0.95 \pm 0.01$ & $16.7 \pm 0.85$ & $51.2 \pm 5.56$ \\
\hline & & & $2.71-2.81$ & $0.50-0.60$ & $0.94-0.96$ & $15.8-17.4$ & $46.4-57.3$ \\
\hline \multirow[t]{2}{*}{ Rape honeys } & 5 & 15 & $5.13 \pm 1.66$ & $1.89 \pm 0.83$ & $1.12 \pm 0.83$ & $19.0 \pm 17.2$ & $7.51 \pm 5.71$ \\
\hline & & & $2.21-6.24$ & $0.95-3.21$ & $0.70-2.60$ & $8.48-49.4$ & $3.57-16.1$ \\
\hline \multirow[t]{2}{*}{ Honeydew honeys } & 6 & 18 & $5.34 \pm 1.63$ & $4.52 \pm 1.42$ & $2.00 \pm 1.38$ & $62.1 \pm 4.98$ & $61.0 \pm 23.2$ \\
\hline & & & $2.27-7.11$ & $2.70-6.61$ & $0.68-3.68$ & $52.5-66.1$ & $23.8-85.8$ \\
\hline \multirow[t]{2}{*}{ Multifloral honeys } & 7 & 21 & $3.89 \pm 0.57$ & $1.55 \pm 0.35$ & $2.62 \pm 2.51$ & $34.4 \pm 17.6$ & $37.4 \pm 8.72$ \\
\hline & & & $2.80-4.45$ & $1.20-2.25$ & $0.49-5.82$ & $10.6-55.6$ & $27.4-45.3$ \\
\hline \multirow[t]{2}{*}{ Heather honeys } & 2 & 6 & $7.28 \pm 1.87$ & $1.65 \pm 0.14$ & $5.55 \pm 5.09$ & $53.2 \pm 8.27$ & $57.7 \pm 9.19$ \\
\hline & & & $5.95-8.60$ & $1.55-1.75$ & $1.95-9.15$ & $47.3-59$ & $51.2-64.2$ \\
\hline \multirow[t]{2}{*}{ Artificial honeys } & 2 & 6 & $6.54 \pm 0.04$ & $0.28 \pm 0.11$ & $13.1 \pm 5.50$ & $1.20 \pm 0.16$ & $3.57 \pm 0.00$ \\
\hline & & & $6.51-6.57$ & $0.20-0.35$ & $9.22-17.0$ & $1.11-1.34$ & $3.57-3.57$ \\
\hline \multicolumn{8}{|l|}{ Syrup-feed honeys } \\
\hline \multirow[t]{2}{*}{ Aloe syrup-feed honey } & 1 & 3 & $7.32 \pm 0.35$ & $1.57 \pm 0.15$ & $1.00 \pm 0.03$ & $11.1 \pm 1.05$ & $7.14 \pm 0.01$ \\
\hline & & & $7.03-7.70$ & $1.41-1.70$ & $0.98-1.02$ & $10.0-12.1$ & $7.14-7.15$ \\
\hline \multirow[t]{2}{*}{ Chokeberry syrup-feed honey } & 1 & 3 & $4.35 \pm 0.22$ & $2.80 \pm 0.00$ & $1.72 \pm 0.02$ & $22.3 \pm 0.60$ & $7.14 \pm 0.01$ \\
\hline & & & $4.20-4.51$ & $2.80-2.81$ & $1.71-1.73$ & $21.8-23.0$ & $7.13-7.15$ \\
\hline \multirow[t]{2}{*}{ Crataegus syrup-feed honey } & 1 & 3 & $4.30 \pm 0.28$ & $2.65 \pm 0.07$ & $0.60 \pm 0.03$ & $31.7 \pm 0.64$ & $29.7 \pm 2.09$ \\
\hline & & & $4.10-4.50$ & $2.60-2.70$ & $0.57-0.62$ & $31.2-32.4$ & $28.5-32.1$ \\
\hline \multirow[t]{2}{*}{ Stinging nettle syrup-feed honey } & 1 & 3 & $7.56 \pm 0.64$ & $2.47 \pm 0.06$ & $1.74 \pm 0.10$ & $25.7 \pm 0.21$ & $27.4 \pm 2.03$ \\
\hline & & & $7.10-8.01$ & $2.40-2.50$ & $1.63-1.82$ & $25.5-25.9$ & $25.0-28.6$ \\
\hline \multirow[t]{2}{*}{ Pine syrup-feed honey } & 1 & 3 & $3.50 \pm 0.004$ & $1.77 \pm 0.15$ & $0.89 \pm 0.07$ & $17.2 \pm 0.21$ & $27.4 \pm 2.01$ \\
\hline & & & $3.50-3.51$ & $1.60-1.90$ & $0.84-0.94$ & $17.1-17.4$ & $25.1-28.6$ \\
\hline \multirow[t]{2}{*}{ Syrup-feed honey } & 1 & 3 & $2.25 \pm 0.23$ & $2.55 \pm 0.34$ & $0.85 \pm 0.07$ & $25.6 \pm 0.63$ & $14.3 \pm 0.01$ \\
\hline & & & $2.09-2.41$ & $2.31-2.79$ & $0.81-0.93$ & $25.2-26.3$ & $14.3-14.3$ \\
\hline \multicolumn{8}{|l|}{ Honeys with natural additives } \\
\hline \multirow[t]{2}{*}{ Bee honey with chokeberry } & 1 & 3 & $6.90 \pm 0.30$ & $5.91 \pm 0.29$ & $1.36 \pm 0.04$ & $31.1 \pm 1.33$ & $23.8 \pm 2.07$ \\
\hline & & & $6.69-7.11$ & $5.71-6.12$ & $1.33-1.39$ & $30.1-32.6$ & $21.4-25.0$ \\
\hline
\end{tabular}


Table 4 (continued)

\begin{tabular}{|c|c|c|c|c|c|c|c|}
\hline Product & $N$ & $n$ & $\mathrm{Ca}$ & $\mathrm{Mg}$ & $\mathrm{Na}$ & $\mathrm{K}$ & $\mathrm{P}$ \\
\hline \multirow[t]{2}{*}{ Bee honey with cinnamon } & 1 & 3 & $12.9 \pm 0.97$ & $2.93 \pm 0.22$ & $1.38 \pm 0.06$ & $33.0 \pm 0.62$ & $23.2 \pm 2.57$ \\
\hline & & & $12.1-14.0$ & $2.80-3.19$ & $1.32-1.45$ & $32.4-33.6$ & $21.4-25.1$ \\
\hline \multirow[t]{2}{*}{ Bee honey with pollen } & 1 & 3 & $6.30 \pm 0.70$ & $5.80 \pm 0.14$ & $1.50 \pm 0.10$ & $42.7 \pm 0.39$ & $76.2 \pm 2.07$ \\
\hline & & & $5.80-6.80$ & $5.70-5.90$ & $1.43-1.57$ & $42.3-43.1$ & $74.9-78.6$ \\
\hline \multirow[t]{2}{*}{ Royal jelly in honey } & 1 & 3 & $7.34 \pm 0.32$ & $2.00 \pm 0.10$ & $0.72 \pm 0.01$ & $17.9 \pm 0.27$ & $40.5 \pm 2.07$ \\
\hline & & & $7.11-7.71$ & $1.90-2.10$ & $0.71-0.73$ & $17.7-18.2$ & $39.3-42.9$ \\
\hline \multirow[t]{2}{*}{ Propolis in honey } & 1 & 3 & $17.3 \pm 0.42$ & $15.9 \pm 0.11$ & $2.43 \pm 0.002$ & $54.2 \pm 0.60$ & $108 \pm 2.03$ \\
\hline & & & $17.0-17.6$ & $15.8-16.0$ & $2.42-2.43$ & $53.7-54.8$ & $107-111$ \\
\hline \multirow[t]{2}{*}{ Acacia honey with almonds ${ }^{\mathrm{a}}$} & 1 & 3 & $3.47 \pm 0.23$ & $2.20 \pm 0.10$ & $0.62 \pm 0.01$ & $19.8 \pm 0.07$ & $25.0 \pm 0.02$ \\
\hline & & & $3.20-3.61$ & $2.10-2.31$ & $0.61-0.62$ & $19.7-19.9$ & $25.0-25.0$ \\
\hline \multirow[t]{2}{*}{ Acacia honey with peanuts ${ }^{\mathrm{a}}$} & 1 & 3 & $2.10 \pm 0.14$ & $4.27 \pm 0.30$ & $0.59 \pm 0.01$ & $48.7 \pm 0.18$ & $46.4 \pm 0.08$ \\
\hline & & & $2.00-2.20$ & $4.00-4.60$ & $0.58-0.59$ & $48.6-49.0$ & $46.4-46.5$ \\
\hline \multicolumn{8}{|l|}{ Bee products } \\
\hline \multirow[t]{2}{*}{ Propolis } & 2 & 6 & $78.0 \pm 10.3$ & $25.3 \pm 0.35$ & $9.23 \pm 7.59$ & $49.9 \pm 2.12$ & $573 \pm 50.9$ \\
\hline & & & $70.7-85.2$ & $25.0-25.5$ & $3.86-14.6$ & $48.4-51.4$ & $537-609$ \\
\hline \multirow[t]{2}{*}{ Bee pollen } & 4 & 12 & $95.1 \pm 13.8$ & $77.4 \pm 20.4$ & $5.86 \pm 5.33$ & $70.0 \pm 0.53$ & $659 \pm 46.3$ \\
\hline & & & $81.4-111$ & $48.9-92.4$ & $2.35-13.8$ & $69.3-70.4$ & $611-722$ \\
\hline \multicolumn{8}{|l|}{ Other } \\
\hline \multirow[t]{2}{*}{ Almonds ${ }^{\mathrm{a}}$} & 1 & 3 & $160 \pm 9.99$ & $136 \pm 1.93$ & $0.51 \pm 0.01$ & $69.0 \pm 0.54$ & $91.6 \pm 5.46$ \\
\hline & & & $151-171$ & $134-138$ & $0.50-0.52$ & $68.4-69.5$ & $85.7-96.4$ \\
\hline \multirow[t]{2}{*}{ Peanuts $^{\mathrm{a}}$} & 1 & 3 & $23.1 \pm 2.30$ & $105 \pm 8.16$ & $1.43 \pm 0.02$ & $68.6 \pm 1.27$ & $107 \pm 5.10$ \\
\hline & & & $21.4-24.7$ & $99.2-111$ & $1.41-1.44$ & $67.7-69.5$ & $104-111$ \\
\hline
\end{tabular}

$N$ number of products, $n$ number of analytical subsamples

${ }^{a}$ Honey and its additives were analyzed separately

$0.32 \mathrm{mg} 100 \mathrm{~g}^{-1}$, respectively. The latter was conducted on 55 honey samples, which consisted of three different types of honey: honeydew, buckwheat, and rape honey. Comparable results for $\mathrm{Zn}$ are reported by Devillers et al. (2002), Kump et al. (1996), Latorre et al. (1999), Terrab et al. (2003), Tuzen et al. (2007), and Yilmaz and Yavuz (1999).

The lowest mean $\mathrm{Cu}$ concentration was determined in acacia, orange, and rape honeys $-0.01 \mathrm{mg} 100 \mathrm{~g}^{-1}$ (Table 5). The mean $\mathrm{Cu}$ values were significantly higher in apple honeys, propolis in honey, propolis, and bee pollen samples amounting to $0.22,0.18,0.46$, and $0.91 \mathrm{mg} 100 \mathrm{~g}^{-1}$, respectively. Chudzinska and Baralkiewicz (2010) reported $\mathrm{Cu}$ concentration in buck-

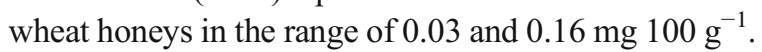
According to Szefer and Grembecka (2007), Cu levels in honeys were in the range of $<0.005$ (acacia and Galician honeys) and $0.18 \mathrm{mg} 100 \mathrm{~g}^{-1}$ (orange and sesame honeys). Tuzen et al. (2007) determined $\mathrm{Cu}$ in the range of $0.02-0.24 \mathrm{mg} 100 \mathrm{~g}^{-1}$ in multifloral honey samples from different regions of Turkey.

Fe levels in the samples analyzed ranged from 0.03

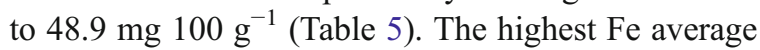
content was obtained for propolis (26.1 mg $\left.100 \mathrm{~g}^{-1}\right)$. Lower values of Fe than these obtained in this study are reported by Souci et al. (2002) and Kunachowicz et al. (2005). While Devillers et al. (2002) determined comparable levels of Fe, Kump et al. (1996) determined higher ones, i.e., $0.76 \mathrm{mg} 100 \mathrm{~g}^{-1}$. Fe concentrations in honeys are comparable with those observed by Conti (2000); Latorre et al. (1999) and Terrab et al. (2003). Turkish honeys contained Fe in the range of 0.18-1.02 mg (Tuzen et al. 2007).

Also in the case of $\mathrm{Mn}$, its average concentration was found to be the highest in propolis samples, i.e., $2.39 \mathrm{mg} 100 \mathrm{~g}^{-1}$. Mn concentrations in honeys are comparable with those observed by Conti (2000), Latorre et al. (1999), and Terrab et al. (2003). Al- 
Table 5 Concentration of the microelements and toxic metals studied in honeys and bee products in milligrams per $100 \mathrm{~g}$ of wet weight $(\bar{x} \pm \mathrm{SD}$, range $)$

\begin{tabular}{|c|c|c|c|c|c|c|c|c|c|c|c|}
\hline Product & $N$ & $n$ & $\mathrm{Zn}$ & $\mathrm{Cu}$ & $\mathrm{Fe}$ & $\mathrm{Mn}$ & $\mathrm{Cr}$ & $\mathrm{Ni}$ & Co & $\mathrm{Pb}$ & $\mathrm{Cd}$ \\
\hline \multicolumn{12}{|l|}{ Honeys } \\
\hline \multirow[t]{2}{*}{ Acacia honeys } & \multirow[t]{2}{*}{3} & \multirow[t]{2}{*}{15} & $0.41 \pm 0.39$ & $0.01 \pm 0.00$ & $0.12 \pm 0.11$ & $0.05 \pm 0.03$ & \multirow[t]{2}{*}{ ND } & $0.03 \pm 0.00$ & $0.01 \pm 0.01$ & \multirow[t]{2}{*}{ ND } & \multirow[t]{2}{*}{ ND } \\
\hline & & & $0.02-0.95$ & $0.01-0.02$ & $0.04-0.29$ & $0.01-0.07$ & & $<0.02-0.03$ & $<0.01-0.02$ & & \\
\hline \multirow[t]{2}{*}{ Eucalyptus honey } & \multirow[t]{2}{*}{1} & \multirow[t]{2}{*}{3} & $0.08 \pm 0.01$ & $0.02 \pm 0.001$ & $0.11 \pm 0.004$ & $0.10 \pm 0.01$ & $0.03 \pm 0.001$ & $0.03 \pm 0.003$ & ND & \multirow[t]{2}{*}{ ND } & \multirow[t]{2}{*}{ ND } \\
\hline & & & $0.07-0.08$ & $0.01-0.02$ & $0.10-0.11$ & $0.09-0.11$ & $0.03-0.03$ & $0.03-0.04$ & & & \\
\hline \multirow[t]{2}{*}{ Buckwheat honeys } & \multirow[t]{2}{*}{6} & \multirow[t]{2}{*}{19} & $0.38 \pm 0.24$ & $0.07 \pm 0.02$ & $0.67 \pm 1.00$ & $0.47 \pm 0.15$ & \multirow[t]{2}{*}{ ND } & $0.05 \pm 0.02$ & $0.01 \pm 0.01$ & \multirow[t]{2}{*}{ ND } & \multirow[t]{2}{*}{ ND } \\
\hline & & & $0.08-0.74$ & $0.05-0.09$ & $0.06-2.64$ & $0.33-0.70$ & & $<0.02-0.06$ & $<0.01-0.02$ & & \\
\hline \multirow[t]{2}{*}{ Apple honey } & \multirow[t]{2}{*}{1} & \multirow[t]{2}{*}{3} & $0.11 \pm 0.01$ & $0.22 \pm 0.01$ & $0.57 \pm 0.02$ & $0.12 \pm 0.01$ & ND & $0.03 \pm 0.002$ & $0.01 \pm 0.001$ & $\mathrm{ND}$ & ND \\
\hline & & & $0.10-0.12$ & $0.21-0.23$ & $0.55-0.59$ & $0.12-0.13$ & & $0.03-0.03$ & $0.01-0.01$ & & \\
\hline Chestnut honey & 1 & 3 & $0.07 \pm 0.003$ & $0.06 \pm 0.003$ & $0.14 \pm 0.001$ & $0.08 \pm 0.004$ & $0.05 \pm 0.004$ & ND & $<0.01$ & ND & ND \\
\hline & & & $0.07-0.07$ & $0.06-0.07$ & $0.14-0.14$ & $0.07-0.08$ & $0.04-0.05$ & & & & \\
\hline Lime honeys & 7 & 21 & $0.84 \pm 0.54$ & $0.03 \pm 0.01$ & $0.25 \pm 0.18$ & $0.11 \pm 0.07$ & $0.02 \pm 0.02$ & $0.04 \pm 0.04$ & $0.02 \pm 0.01$ & $\mathrm{ND}$ & ND \\
\hline & & & $0.05-1.69$ & $0.01-0.05$ & $0.04-0.30$ & $0.05-0.22$ & $<0.02-0.04$ & $<0.02-0.08$ & $<0.01-0.02$ & & \\
\hline Dandelion honey & 1 & 3 & $0.65 \pm 0.04$ & $0.03 \pm 0.003$ & $0.08 \pm 0.003$ & $0.09 \pm 0.01$ & ND & $0.03 \pm 0.003$ & $0.03 \pm 0.002$ & $\mathrm{ND}$ & ND \\
\hline & & & $0.62-0.68$ & $0.03-0.03$ & $0.08-0.09$ & $0.08-0.10$ & & $0.03-0.03$ & $0.03-0.03$ & & \\
\hline Orange honey & 1 & 3 & $0.05 \pm 0.001$ & $0.01 \pm 0.001$ & $0.08 \pm 0.01$ & $0.01 \pm 0.001$ & $0.03 \pm 0.002$ & $0.03 \pm 0.002$ & $<0.01$ & ND & ND \\
\hline & & & $0.05-0.05$ & $0.01-0.01$ & $0.08-0.09$ & $0.01-0.01$ & $0.03-0.04$ & $0.03-0.04$ & & & \\
\hline Rape honeys & 5 & 15 & $0.21 \pm 0.17$ & $0.01 \pm 0.00$ & $0.30 \pm 0.31$ & $0.06 \pm 0.05$ & ND & $0.03 \pm 0.006$ & ND & ND & ND \\
\hline & & & $0.07-0.44$ & $0.01-0.02$ & $0.11-0.84$ & $0.03-0.15$ & & $<0.02-0.04$ & & & \\
\hline Honeydew honeys & 6 & 18 & $0.52 \pm 0.65$ & $0.09 \pm 0.03$ & $0.27 \pm 0.16$ & $0.35 \pm 0.10$ & ND & $0.04 \pm 0.03$ & $0.02 \pm 0.02$ & ND & ND \\
\hline & & & $0.09-1.82$ & $0.03-0.12$ & $0.07-0.37$ & $0.17-0.49$ & & $0.01-0.09$ & $<0.01-0.04$ & & \\
\hline Multifloral honeys & 7 & 21 & $0.38 \pm 0.41$ & $0.02 \pm 0.01$ & $0.18 \pm 0.22$ & $0.09 \pm 0.07$ & $0.04 \pm 0.003$ & $0.04 \pm 0.02$ & $0.01 \pm 0.001$ & $\mathrm{ND}$ & ND \\
\hline & & & $0.06-1.03$ & $0.01-0.03$ & $0.03-0.63$ & $0.02-0.18$ & $<0.02-0.04$ & $0.01-0.08$ & $<0.01-0.01$ & & \\
\hline Heather honeys & 2 & 6 & $0.81 \pm 0.12$ & $0.03 \pm 0.00$ & $0.14 \pm 0.01$ & $0.80 \pm 0.38$ & $0.02 \pm 0.01$ & $0.07 \pm 0.04$ & ND & $\mathrm{ND}$ & ND \\
\hline & & & $0.72-0.89$ & $0.03-0.03$ & $0.13-0.14$ & $0.53-1.07$ & $<0.02-0.02$ & $0.04-0.10$ & & & \\
\hline Artificial honeys & 2 & 6 & $0.03 \pm 0.00$ & $0.02 \pm 0.01$ & $0.06 \pm 0.04$ & $0.01 \pm 0.01$ & $0.02 \pm 0.00$ & ND & ND & ND & ND \\
\hline & & & $0.03-0.03$ & $0.01-0.02$ & $0.03-0.08$ & $0.01-0.02$ & $0.02-0.02$ & & & & \\
\hline Syrup-feed honeys & & & & & & & & & & & \\
\hline Aloe sy & 1 & 3 & $0.14 \pm 0.001$ & $0.01 \pm 0.001$ & $0.18 \pm 0.02$ & $0.06 \pm 0.001$ & ND & ND & ND & $\mathrm{ND}$ & ND \\
\hline & & & $0.14-0.14$ & $0.01-0.01$ & $0.17-0.20$ & $0.06-0.06$ & & & & & \\
\hline Chokeberry & 1 & 3 & $0.05 \pm 0.001$ & $0.01 \pm 0.000$ & $0.36 \pm 0.02$ & $0.10 \pm 0.001$ & ND & $0.02 \pm 0.001$ & $0.02 \pm 0.001$ & ND & ND \\
\hline & & & $0.05-0.05$ & $0.01-0.01$ & $0.34-0.37$ & $0.10-0.10$ & & $0.02-0.03$ & $0.02-0.02$ & & \\
\hline Crataegus & 1 & 3 & $0.06 \pm 0.002$ & $0.02 \pm 0.001$ & $0.14 \pm 0.01$ & $0.06 \pm 0.003$ & ND & ND & ND & $\mathrm{ND}$ & ND \\
\hline & & & $0.06-0.06$ & $0.02-0.02$ & $0.14-0.15$ & $0.06-0.07$ & & & & & \\
\hline Stingin & 1 & 3 & $0.79 \pm 0.01$ & $0.01 \pm 0.001$ & $0.41 \pm 0.01$ & $0.06 \pm 0.003$ & ND & $0.03 \pm 0.003$ & $0.01 \pm 0.001$ & ND & ND \\
\hline & & & $0.78-0.80$ & $0.01-0.01$ & $0.40-0.41$ & $0.05-0.06$ & & $0.02-0.03$ & $0.01-0.01$ & & \\
\hline Pine & 1 & 3 & $0.14 \pm 0.004$ & $0.01 \pm 0.001$ & $0.23 \pm 0.01$ & $0.08 \pm 0.003$ & ND & $0.09 \pm 0.01$ & ND & ND & ND \\
\hline & & & $0.14-0.15$ & $0.01-0.01$ & $0.21-0.23$ & $0.08-0.08$ & & $0.08-0.10$ & & & \\
\hline Syrup-feed honey & 1 & 3 & $0.26 \pm 0.01$ & $0.02 \pm 0.000$ & $0.46 \pm 0.01$ & $0.02 \pm 0.001$ & $0.02 \pm 0.002$ & $0.04 \pm 0.001$ & ND & $\mathrm{ND}$ & ND \\
\hline & & & $0.25-0.26$ & $0.01-0.02$ & $0.46-0.47$ & $0.02-0.02$ & $0.02-0.02$ & $0.03-0.04$ & & & \\
\hline Honeys with natur & ad & IUT & & & & & & & & & \\
\hline Bee honey with & 1 & 3 & $0.35 \pm 0.01$ & $0.02 \pm 0.001$ & $0.12 \pm 0.01$ & $0.06 \pm 0.002$ & ND & ND & $0.01 \pm 0.001$ & $\mathrm{ND}$ & ND \\
\hline & & & $0.34-0.36$ & $0.02-0.02$ & $0.11-0.12$ & $0.06-0.06$ & & & $0.01-0.01$ & & \\
\hline
\end{tabular}


Table 5 (continued)

\begin{tabular}{|c|c|c|c|c|c|c|c|c|c|c|c|}
\hline Product & $N$ & $n$ & $\mathrm{Zn}$ & $\mathrm{Cu}$ & $\mathrm{Fe}$ & $\mathrm{Mn}$ & $\mathrm{Cr}$ & $\mathrm{Ni}$ & $\mathrm{Co}$ & $\mathrm{Pb}$ & $\mathrm{Cd}$ \\
\hline \multirow{2}{*}{$\begin{array}{l}\text { Bee honey with } \\
\text { cinnamon }\end{array}$} & \multirow[t]{2}{*}{1} & \multirow[t]{2}{*}{3} & $0.35 \pm 0.03$ & $0.02 \pm 0.002$ & $0.26 \pm 0.003$ & $0.25 \pm 0.01$ & \multirow[t]{2}{*}{$\mathrm{ND}$} & \multirow[t]{2}{*}{ ND } & \multirow[t]{2}{*}{ ND } & \multirow[t]{2}{*}{$\mathrm{ND}$} & \multirow[t]{2}{*}{ ND } \\
\hline & & & $0.33-0.38$ & $0.02-0.03$ & $0.25-0.26$ & $0.24-0.26$ & & & & & \\
\hline \multirow{2}{*}{$\begin{array}{l}\text { Bee honey with } \\
\text { pollen }\end{array}$} & \multirow[t]{2}{*}{1} & \multirow[t]{2}{*}{3} & $0.50 \pm 0.01$ & $0.04 \pm 0.003$ & $0.27 \pm 0.02$ & $0.17 \pm 0.01$ & \multirow[t]{2}{*}{ ND } & \multirow[t]{2}{*}{$\mathrm{ND}$} & \multirow[t]{2}{*}{ ND } & \multirow[t]{2}{*}{$\mathrm{ND}$} & \multirow[t]{2}{*}{ ND } \\
\hline & & & $0.49-0.51$ & $0.03-0.04$ & $0.24-0.28$ & $0.16-0.17$ & & & & & \\
\hline \multirow{2}{*}{$\begin{array}{l}\text { Royal jelly in } \\
\text { honey }\end{array}$} & \multirow[t]{2}{*}{1} & \multirow[t]{2}{*}{3} & $0.12 \pm 0.000$ & $0.02 \pm 0.001$ & $0.20 \pm 0.003$ & $0.07 \pm 0.01$ & \multirow[t]{2}{*}{ ND } & $0.03 \pm 0.002$ & $0.01 \pm 0.000$ & \multirow[t]{2}{*}{ ND } & \multirow[t]{2}{*}{ ND } \\
\hline & & & $0.12-0.12$ & $0.02-0.02$ & $0.20-0.20$ & $0.07-0.08$ & & $0.03-0.03$ & $0.01-0.01$ & & \\
\hline \multirow{2}{*}{$\begin{array}{l}\text { Propolis in } \\
\text { honey }\end{array}$} & \multirow[t]{2}{*}{1} & \multirow[t]{2}{*}{3} & $0.82 \pm 0.04$ & $0.18 \pm 0.02$ & $2.92 \pm 0.10$ & $0.43 \pm 0.002$ & \multirow[t]{2}{*}{$\mathrm{ND}$} & \multirow[t]{2}{*}{ ND } & $0.01 \pm 0.001$ & \multirow[t]{2}{*}{ ND } & \multirow[t]{2}{*}{ ND } \\
\hline & & & $0.80-0.87$ & $0.17-0.19$ & $2.83-3.03$ & $0.43-0.43$ & & & $0.01-0.02$ & & \\
\hline \multirow{2}{*}{$\begin{array}{l}\text { Acacia honey } \\
\text { with almonds }\end{array}$} & \multirow[t]{2}{*}{1} & \multirow[t]{2}{*}{3} & $0.02 \pm 0.001$ & $0.01 \pm 0.001$ & $0.15 \pm 0.01$ & $0.02 \pm 0.001$ & ND & $0.09 \pm 0.003$ & ND & ND & ND \\
\hline & & & $0.02-0.02$ & $0.01-0.01$ & $0.15-0.16$ & $0.02-0.02$ & & $0.09-0.09$ & & & \\
\hline Acacia honey & 1 & 3 & $0.12 \pm 0.01$ & $0.02 \pm 0.002$ & $0.10 \pm 0.002$ & $0.02 \pm 0.001$ & ND & $0.12 \pm 0.01$ & ND & $\mathrm{ND}$ & ND \\
\hline with peanuts ${ }^{\mathrm{a}}$ & & & $0.12-0.13$ & $0.02-0.02$ & $0.10-0.10$ & $0.02-0.02$ & & $0.11-0.12$ & & & \\
\hline Bee products & & & & & & & & & & & \\
\hline Propolis & 2 & 6 & $4.33 \pm 0.21$ & $0.46 \pm 0.14$ & $26.1 \pm 32.2$ & $2.39 \pm 0.11$ & $0.67 \pm 0.16$ & $0.12 \pm 0.01$ & $0.02 \pm 0.01$ & $\mathrm{ND}$ & ND \\
\hline & & & $4.18-4.48$ & $0.36-0.56$ & $3.37-48.9$ & $2.31-2.46$ & $0.56-0.78$ & $0.11-0.12$ & $0.01-0.02$ & & \\
\hline Bee pollen & 4 & 12 & $2.90 \pm 0.16$ & $0.91 \pm 0.17$ & $3.70 \pm 0.30$ & $1.90 \pm 0.45$ & $0.03 \pm 0.01$ & $0.13 \pm 0.14$ & $0.03 \pm 0.01$ & ND & ND \\
\hline & & & $2.70-3.06$ & $0.73-1.12$ & $3.26-3.96$ & $1.40-2.47$ & $0.02-0.03$ & $0.03-0.33$ & $0.02-0.04$ & & \\
\hline Other & & & & & & & & & & & \\
\hline Almonds ${ }^{\mathrm{a}}$ & 1 & 3 & $1.81 \pm 0.07$ & $0.73 \pm 0.03$ & $1.94 \pm 0.02$ & $1.51 \pm 0.12$ & $0.03 \pm 0.002$ & ND & $0.01 \pm 0.001$ & $\mathrm{ND}$ & ND \\
\hline & & & $1.75-1.89$ & $0.71-0.75$ & $1.92-1.95$ & $1.43-1.60$ & $0.03-0.03$ & & $0.01-0.01$ & & \\
\hline Peanuts $^{\mathrm{a}}$ & 1 & 3 & $1.72 \pm 0.01$ & $0.44 \pm 0.03$ & $0.85 \pm 0.07$ & $1.31 \pm 0.12$ & $0.02 \pm 0.001$ & ND & $0.01 \pm 0.001$ & $\mathrm{ND}$ & ND \\
\hline & & & $1.71-1.73$ & $0.42-0.46$ & $0.81-0.90$ & $1.22-1.39$ & $0.01-0.02$ & & $0.01-0.01$ & & \\
\hline
\end{tabular}

$N$ number of products, $n$ number of analytical subsamples, $N D$ not detected. LOD for $\mathrm{Cd}=0.003 \mathrm{mg}^{2} 00 \mathrm{~g}^{-1}, \mathrm{~Pb}=0.01 \mathrm{mg} 100 \mathrm{~g}^{-1}$, $\mathrm{Ni}=0.02 \mathrm{mg} 100 \mathrm{~g}^{-1}, \mathrm{Co}=0.01 \mathrm{mg} 100 \mathrm{~g}^{-1}, \mathrm{Cr}=0.02 \mathrm{mg} 100 \mathrm{~g}^{-1}$

${ }^{\mathrm{a}}$ Honey and its additives were analyzed separately

Khalifa and Al-Arify (1999) determined lower levels of this element in honeys, i.e., $0.01 \mathrm{mg} 100 \mathrm{~g}^{-1}$.

Chromium content in the samples analyzed ranged from $<0.02$ to $0.67 \mathrm{mg} 100 \mathrm{~g}^{-1}$ (Table 5). Higher $\mathrm{Cr}$ concentrations were determined in honeys by Devillers et al. (2002) and Kump et al. (1996), while lower concentrations were determined by Caroli et al. (1999). According to Souci et al. (2002), Cr concentration in honeys amounted to $0.013 \mathrm{mg} 100 \mathrm{~g}^{-1}$.

The highest $\mathrm{Ni}$ and $\mathrm{Co}$ concentrations were found in bee pollen samples $\left(0.13\right.$ and $0.03 \mathrm{mg} 100 \mathrm{~g}^{-1}$, respectively). Buldini et al. (2001), Devillers et al. (2002), and Latorre et al. (1999) determined comparable levels of $\mathrm{Ni}$ and Co. However, Rashed and Soltan (2004) reported higher levels of both elements $\mathrm{Ni}$ and Co.

Consumption of $25 \mathrm{~g}$ of honeys and bee products supplies the human body with varied amounts of mineral components. In general, the realization of RDA for an adult by $25 \mathrm{~g}$ of all the analyzed honeys (natural, syrup-feed, and with additives) was between $0.22 \%$ and $0.30 \%$ for $\mathrm{Mg}, 0.17 \%$ for $\mathrm{Ca}, 0.03 \%$ for $\mathrm{Na}, 0.17 \%$ for $\mathrm{K}, 1.28 \%$ for $\mathrm{P}, 0.84-1.15 \%$ for $\mathrm{Zn}, 1.03 \%$ for $\mathrm{Cu}$, $0.61-1.10 \%$ for $\mathrm{Fe}$, and $1.65-2.11 \%$ for $\mathrm{Mn}$. The highest average percentages of realization of RDA for adult (Jarosz and Bułhak-Jachymczyk 2008) were obtained for bee products, i.e., 3.58-4.83\% for $\mathrm{Mg}$, $2.24 \%$ for $\mathrm{Ca}, 0.12 \%$ for $\mathrm{Na}, 0.34 \%$ for $\mathrm{K}, 22.5 \%$ for $\mathrm{P}, 7.68-10.6 \%$ for $\mathrm{Zn}, 21.1 \%$ for $\mathrm{Cu}, 15.5-28 \%$ for $\mathrm{Fe}$, and $22.4-28.5 \%$ for $\mathrm{Mn}$.

Levels of toxic elements in all the samples analyzed were $<45 \mu \mathrm{g} 100 \mathrm{~g}^{-1}$ and $<15 \mu \mathrm{g} 100 \mathrm{~g}^{-1}$ for $\mathrm{Pb}$ and $\mathrm{Cd}$, respectively, it means that due to $\mathrm{Cd}$ intake with the analyzed products PTMI is not exceeded. Therefore, it was concluded that there is no health hazard associated with consumption of honeys and bee products. 


\section{Statistical estimate}

\section{Correlation}

The analyzed samples before Spearman's rank correlation analysis were divided into three groups, i.e., natural honeys, syrup-feed honeys, and honeys with natural additives and bee products. The majority of chemical elements exhibited significant positive and negative correlations between their concentrations in honeys and bee products samples. The most significant relationships in natural honeys samples were noted for the following pairs of elements: $\mathrm{Mg}-\mathrm{K}-\mathrm{Cu}-\mathrm{Mn}$ $(p<0.001), \mathrm{Na}-\mathrm{K}(p<0.001), \mathrm{P}-\mathrm{Cu}-\mathrm{Mn}(p<0.001)$, $\mathrm{Zn}-\mathrm{Fe}(p<0.01), \mathrm{Na}-\mathrm{Cu}, \mathrm{Mn}-\mathrm{Cu}, \mathrm{Mg}-\mathrm{P}, \mathrm{K}-\mathrm{P}$, and $\mathrm{Mn}-\mathrm{Na}(p<0.05)$. Significant negative correlations $(p<0.05)$ were observed between the concentrations of $\mathrm{Cu}$ and $\mathrm{Na}$ in syrup-feed honeys. In the case of honeys with natural additives, significant positive relationships were observed for the following assemblages: $\mathrm{Na}-\mathrm{Zn}, \mathrm{K}-\mathrm{Zn}(p<0.01), \mathrm{Na}-\mathrm{Cu}-\mathrm{Fe}-$ $\mathrm{K}, \mathrm{Cu}-\mathrm{P}, \mathrm{Zn}-\mathrm{Cu}$, and $\mathrm{Fe}-\mathrm{Mn}(p<0.05)$. Significant positive relationships were also observed in the group of bee products between such elements as $\mathrm{Mg}$ and $\mathrm{K}(p<0.001), \mathrm{Ca}-\mathrm{Cu}(p<0.01), \mathrm{Ca}-\mathrm{Mn}$, and $\mathrm{Na}-\mathrm{Cu}(p<0.05)$.

\section{ANOVA Kruskal-Wallis test}

The influence of the type, and botanical and geographical provenance on the products' elemental composition was verified by Kruskal-Wallis test. There was a statistically significant influence of botanical origin of honey (acacia, buckwheat, lime, rape, honeydew, multifloral, heather) on $\mathrm{K}, \mathrm{P}, \mathrm{Cu}$, and $\mathrm{Mn}(p<0.001), \mathrm{Mg}$ $(p<0.01)$, and $\mathrm{Ca}(p<0.05)$. The geographical provenance of the product had an influence on $\mathrm{Zn}$ content in honey samples $(p<0.01)$. Levels of some of the analyzed elements in honeys strongly depended on their type (natural honeys, syrup-feed honeys, and honeys with natural additives). Such interdependences were observed in the case of $\mathrm{Ca}, \mathrm{Mg}(p<0.01)$, and $\mathrm{Cu}(p<$ $0.05)$.

\section{Factor analysis}

Application of FA model to data from multi-elemental analysis of natural honeys samples indicated botanical differences between them. The results for honeys data set are presented in Fig. 1a and b. The first two factors explain cumulatively $51.5 \%$ of the total variance; F1 and $\mathrm{F} 2$ account for 35.7 and $15.8 \%$, respectively. The eigenvalues are 3.21 (F1) and 1.42 (F2), respectively. Factor loadings for the elements analyzed are presented in Table 2. Dark color honeys such as honeydew, buckwheat, and heather are generally characterized by lower values of F1, whereas the light color ones, i.e., acacia, lime, rape, and multifloral, by its higher values (Fig. 1a). Thus, factor F1 can be interpreted as a factor distinguishing dark color honeys from light ones. F1 achieves the lowest values for $\mathrm{K}, \mathrm{Cu}, \mathrm{Mn}, \mathrm{P}$, and $\mathrm{Mg}$ (as descriptors for dark color honeys), while the highest for $\mathrm{Zn}, \mathrm{Fe}, \mathrm{Ca}$, and $\mathrm{Na}$ (as descriptors for light color honeys) (Fig. 1b). The lowest F2 values correspond to objects representing buck-
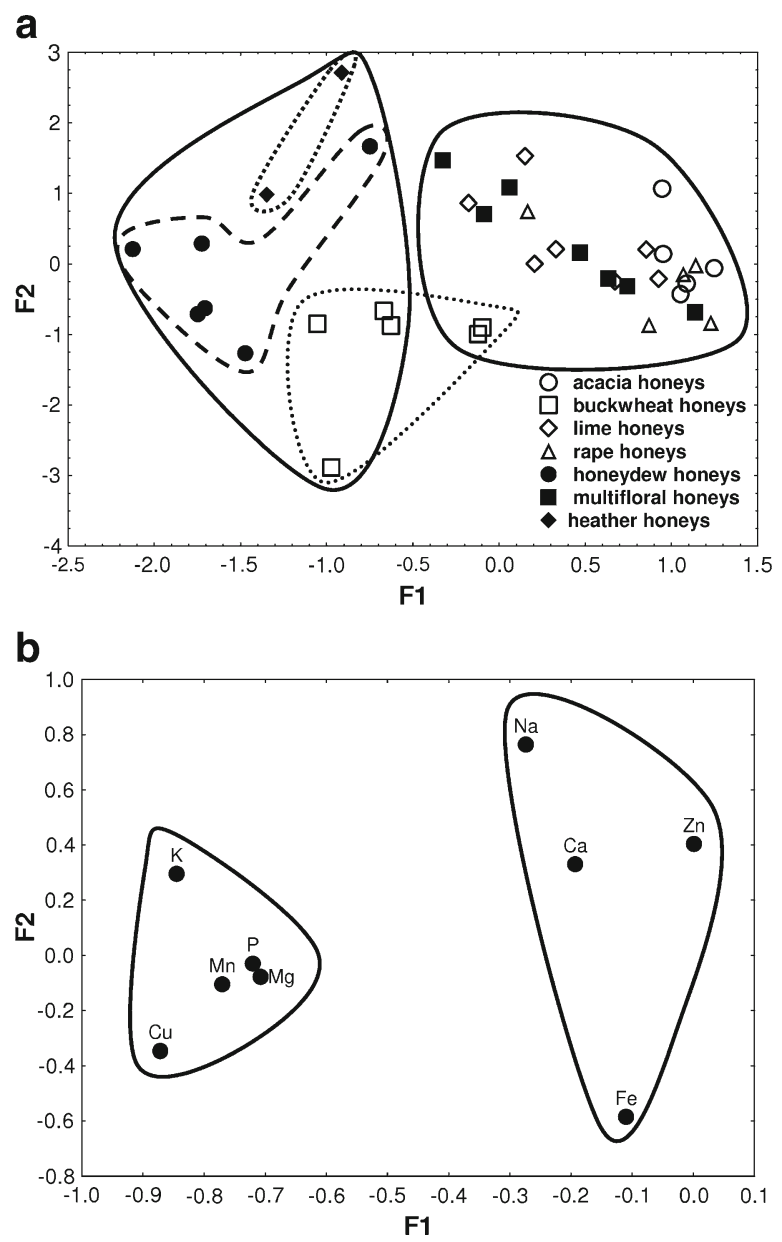

Fig. 1 a Scatterplot of object scores of the two discriminant functions of exclusively natural honeys. b Scatterplot of loadings for nine elements in natural honeys samples 
a

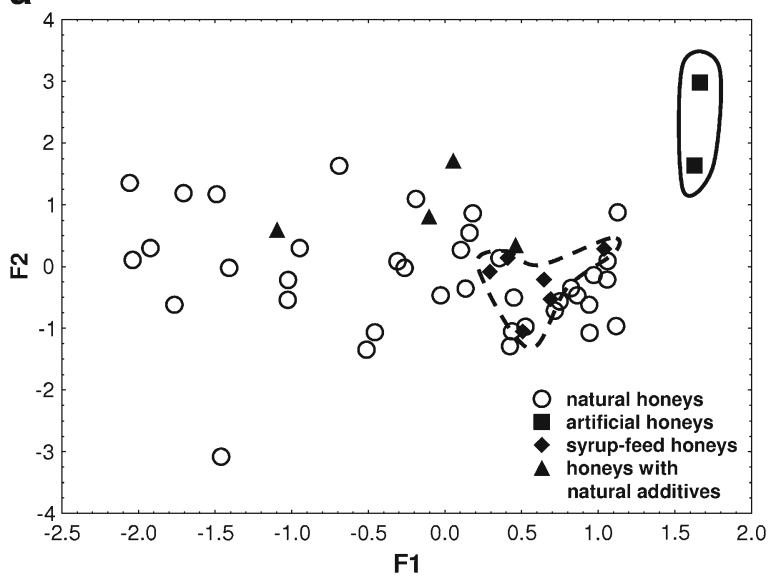

b

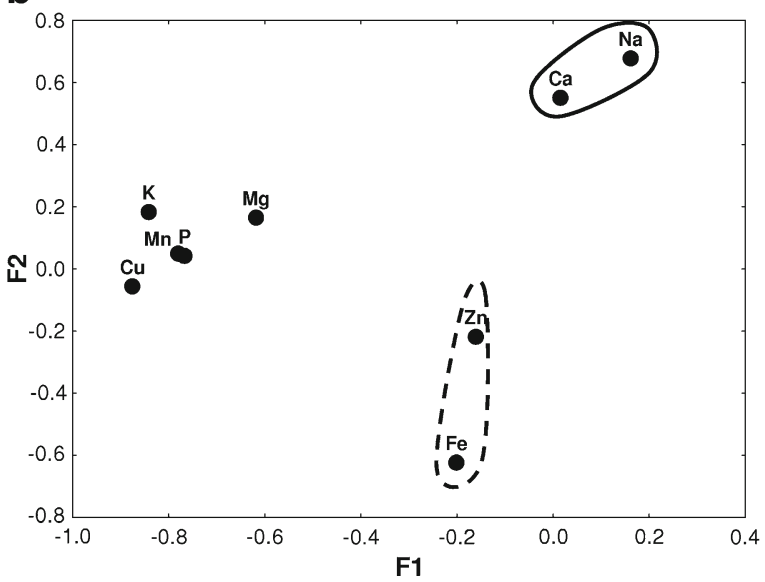

Fig. 2 a Scatterplot of object scores of the two discriminant functions of natural, syrup-feed, artificial, and with natural additives honeys. b Scatterplot of loadings for nine elements in analyzed samples

wheat honey samples that are rich in $\mathrm{Cu}$ and $\mathrm{Fe}$. Higher values of this factor can be associated with heather honeys, which contain greater amounts of $\mathrm{Na}$.

In order to visualize the data structure concerning natural, syrup-feed, artificial, and with natural additives honeys, a factor analysis was carried out and the results depicted in Fig. $2 \mathrm{a}$ and $\mathrm{b}$. The two factors (F1, F2) issued from factor analysis explain cumulatively up to $49.1 \%$ of the total variance, so that $35.0 \%$ is explained by F1 and $14.1 \%$ by F2. The eigenvalues are $3.15(\mathrm{~F} 1)$ and $1.27(\mathrm{~F} 2)$, respectively. Factor loadings for the elements analyzed are presented in Table 3. Figure 2a shows the scatterplot for the studied samples. In order to identify elements responsible for the grouping of the objects (honeys), biplot of loadings was drawn for F1-F2 (Fig. 2b). As can be seen in Fig. 2, higher values of F1 and F2 correspond to artificial honey samples characterized by the highest levels of $\mathrm{Ca}$ and $\mathrm{Na}$. It means that $\mathrm{Ca}$ and $\mathrm{Na}$ are the best descriptors for identification of artificial honeys (Fig. 2b). The lowest F1 values can be associated with natural honeys and those with natural additives described by $\mathrm{K}, \mathrm{P}, \mathrm{Cu}, \mathrm{Mn}$, and $\mathrm{Mg}$ (Fig. 2a, b). The distribution of the points corresponding to the individual elements shows that factor F2 achieves the lowest values for natural and syrup-feed honeys containing great concentration of $\mathrm{Fe}$ and Zn (Fig. 2a, b).

\section{Cluster analysis}

Cluster analysis (CA) was applied in order to identify interrelationships between concentration of selected elements in the studied material on one hand and belonging of honeys to a particular group on the other hand. The numbers of significant clusters in the dendrograms were based on the Sneath index, using $66 \%$ of maximum distance measure. The CA data (hierarchical clustering, Ward's method) for natural honeys as objects is shown in Fig. 3a and b. The dendrogram is built up of two main clusters. The first contains objects, which represents dark color honeys, whereas the latter light color ones. It is also possible to distinguish two subclusters in both of the clusters. The dark color honeys cluster (except C34 and C36) contains samples representing honeydew (C24-C29), buckwheat (C6-C11), and heather honeys (C37, C38), while the second cluster consists of acacia (C1-C5), lime (C12-C18), rape (C19-C23), and multifloral honeys (C30-C36). The obtained information confirms the results of FA analysis for the matrix of natural honeys samples.

Hierarchical dendrogram for the analyzed samples of syrup-feed and with natural additives honeys and artificial ones as objects is depicted in Fig. $4 \mathrm{a}$ and $\mathrm{b}$. There can be distinguished two main clusters, the first one $(\mathrm{C} 1-\mathrm{C} 2)$ contains objects representing artificial honeys while the second syrup-feed and with natural additives honeys. As can be observed, artificial honeys are distinguished by two metals, i.e., $\mathrm{Na}$ and $\mathrm{Ca}$ (Fig. 4b), which was also confirmed by FA analysis. Syrup-feed honeys were generally assigned to one subcluster $(\mathrm{C} 4, \mathrm{C} 5$ and $\mathrm{C} 7$, C8) except for the samples of stinging-nettle and aloe 
Fig. 3 a Hierarchical dendrogram for 38 natural honeys samples as objects. b Hierarchical dendrogram for nine elements as objects
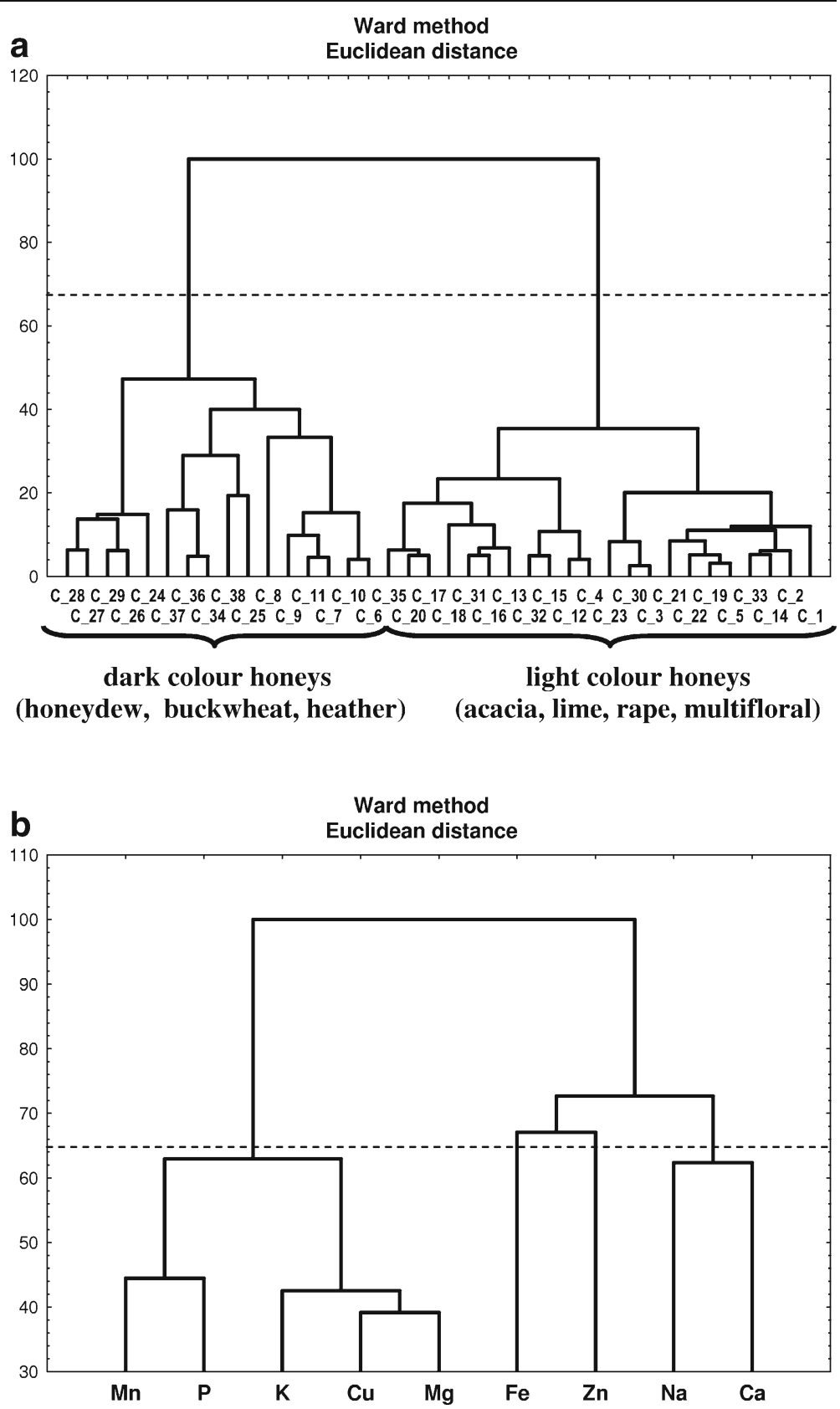

syrup-feed honeys (C3 and C6), which can be found in the subcluster of honeys with natural additives (C9$\mathrm{C} 12$ ). These results have shown that there is a possibility of CA application in fraud detection as artificial honeys are well distinguished from other samples. What is more, it can be concluded that this technique is able, based on mineral composition, to distinguish samples not only of varied type but also in view of their botanical provenance as well as level of technological processing.

\section{Conclusions}

According to the results obtained, honeys and bee products proved to be products that might not only provide significant amounts of energy but also of essential nutrients as $\mathrm{Mg}, \mathrm{K}, \mathrm{Ca}, \mathrm{Zn}, \mathrm{Cu}, \mathrm{Fe}$, and Mn. Generally, darker honeys had a higher mineral content than the light color ones. However, it must be also remembered that the contribution of honey to the 
Fig. 4 a Hierarchical dendrogram for syrup-feed, artificial, and with natural additives honeys as objects. b Hierarchical dendrogram for nine elements as objects
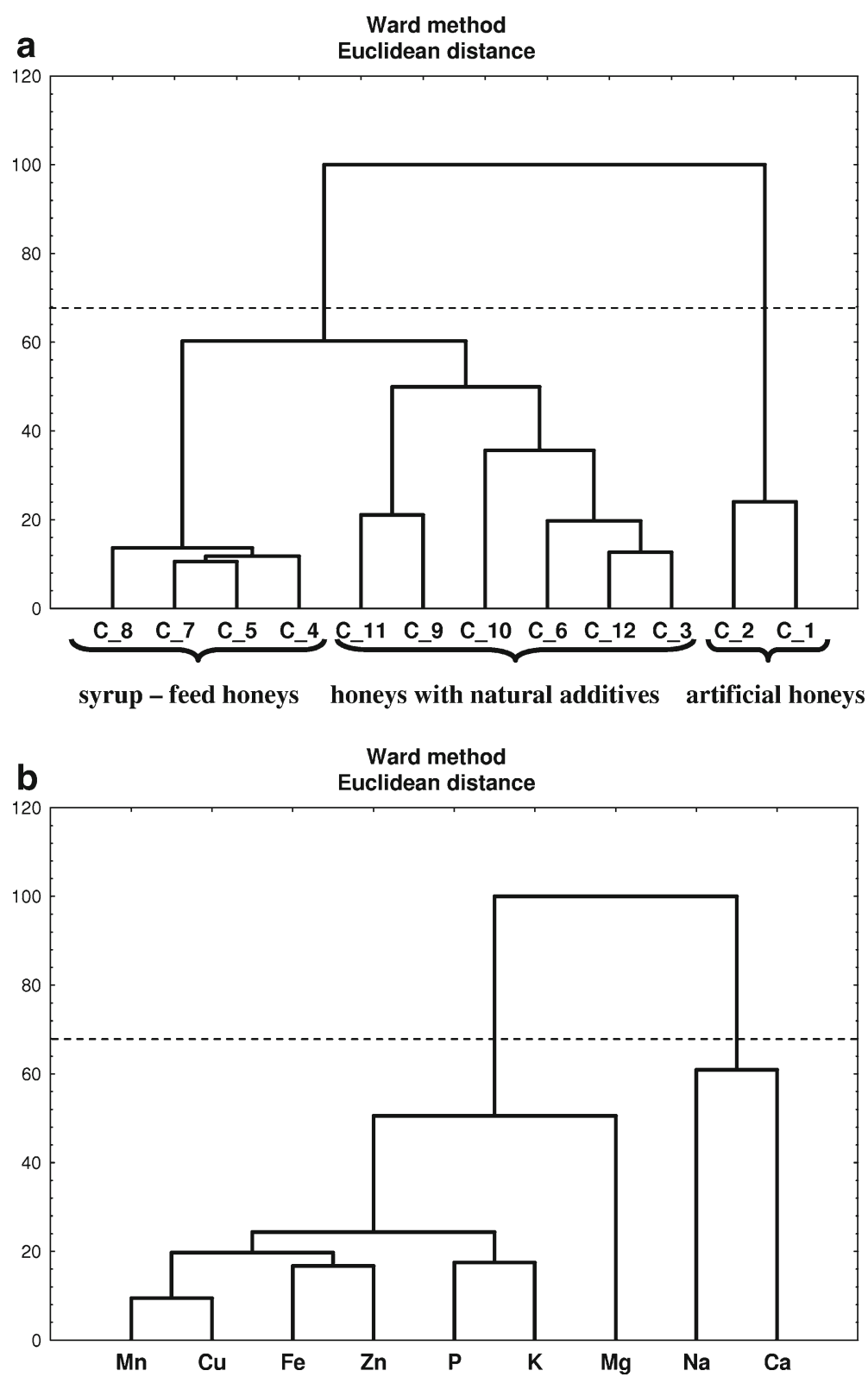

recommended daily intake (RDI) is small, but its importance lies in its physiological effects. Based on RDA estimated for essential elements, it was concluded that bee products such as bee pollen and propolis supply an organism with the biggest amounts of bioelements. In the light of PTMI estimated for toxic elements, there is no health hazard associated with exposure to $\mathrm{Cd}$ and $\mathrm{Pb}$ through the consumption of these products.

Application of ANOVA Kruskal-Wallis test let us reveal a relationship between honey biological provenance and its elemental composition. Macroand microelements levels in the analyzed samples were significantly influenced by the extent of technological processing of samples as well as geographical origin.

Other chemometric techniques such as factor and cluster analyses have proved to be reliable tools in the differentiation of food products in view of their mineral composition. Their application was helpful for a deeper understanding of the distribution of selected metals in food. Moreover, these techniques let us 
clearly separate artificial honey samples from the natural ones, which might be very helpful in detecting fraud or proving authenticity of the product. Based on the obtained results, it can be concluded that multivariate techniques are efficient tools that can be successfully applied to food quality and authenticity evaluation.

Acknowledgments The authors gratefully acknowledge financial support received from grant PB 0676/P052005/28 from the Polish Ministry of Scientific Research and Information Technology. Thanks are also due to Edyta Tomczak for her assistance in sample preparation.

Open Access This article is distributed under the terms of the Creative Commons Attribution License which permits any use, distribution, and reproduction in any medium, provided the original author(s) and the source are credited.

\section{References}

Al-Khalifa, A. S., \& Al-Arify, I. A. (1999). Physicochemical characteristics and pollen spectrum of some Saudi honeys. Food Chemistry, 67, 21-25.

Alvarez-Suarez, J. M., Tulipani, S., Romandini, S., Bertoli, E., \& Battino, M. (2010). Contribution of honey in nutrition and human health: a review. Mediterranean Journal of Nutrition and Metabolism, 3, 15-23.

Brereton, R.G. (2003). Chemometrics: data analysis for the laboratory and chemical plant. New York: Wiley.

Buldini, P. L., Cavalli, S., Mevoli, A., \& Lal Sharma, J. (2001). Ion chromatographic and voltammetric determination of heavy and transition metals in honey. Food Chemistry, 73, 487-495.

Capar, G. S., \& Cunningham, W. C. (2000). Element and radionuclide concentrations in food: FDA total diet study 1991-1996. Journal of AOAC International, 83, 157-177.

Caroli, S., Forte, G., Iamiceli, A. L., \& Galoppi, B. (1999). Determination of essential and potentially toxic trace elements in honey by inductively coupled plasma-based techniques. Talanta, 50, 327-336.

Chudzinska, M., \& Baralkiewicz, D. (2010). Estimation of honey authenticity by multielements characteristics using inductively coupled plasma-mass spectrometry (ICP-MS) combined with chemometrics. Food and Chemical Toxicology, 48, 284-290.

Conti, M. E. (2000). Lazio region (central Italy) honeys: a survey of mineral content and typical quality parameters. Food Control, 11, 459-463.

Devillers, J., Doré, J. C., Marenco, M., Poirier-Duchêne, F., Galand, N., \& Viel, C. (2002). Chemometrical analysis of 18 metallic and nonmetallic elements found in honeys sold in France. Journal of Agricultural and Food Chemistry, 50, 5998-6007.

Dietary Reference Intakes. National Academy of Sciences, 2004. http://fnic.nal.usda.gov/nal_display/index.php?info center $=4 \&$ tax_level=3\&tax_subject $=256 \&$ topic $\mathrm{id}=1342$ \&level $^{-}$id $=5140$

Fernàndez-Torres, R., Pérez-Bernal, J. L., Bello-López, M. Á., Callejón-Mochón, M., Jiménez-Sánchez, J. C., \&
Guiraúm-Pérez, A. (2005). Mineral content and botanical origin of Spanish honeys. Talanta, 65, 686-691.

Hernández, O. M., Fraga, J. M. G., Jiménez, A. I., Jiménez, F., \& Arias, J. J. (2005). Characterization of honey from the Canary Islands: determination of the mineral content by atomic absorption spectrophotometry. Food Chemistry, 93, 449-458.

Jarosz, M., \& Bułhak-Jachymczyk, B. (2008). Normy Żywienia Człowieka. Podstawy Prewencji Otyłości i Chorób Niezakaźnych. Warszawa: Wydawnictwo Lekarskie PZWL. in Polish.

Kanoniuk, D., Podgórski, G., \& Unkiewicz-Winiarczyk, A. (2004). Zawartość Ca, Mg, Fe i Cd w miodach nektarowych i spadziowych z terenów niezubanizowanych i zurbanizowanych. Roczniki PZH, 55, 77-80.

Konieczka, P., \& Namieśnik, J. (2009). Quality assurance and quality control in the analytical chemical laboratory: a practical approach. Boca Raton: CRC.

Kump, P., Nečemer, M., \& Šnajder, J. (1996). Determination of trace elements in bee honey, pollen and tissue by total reflection and radioisotope X-ray fluorescence spectrometry. Spectrochimica Acta Part B, 51, 499-507.

Kunachowicz, H., Nadolna, I., Przygoda, B., \& Iwanow, K. (2005). Tabele składu $i$ wartości odżywczej żywności. Warszawa: Wydawnictwo Lekarskie PZWL. in Polish.

Latorre, M. J., Peña, R., Pita, C., Botana, A., García, S., \& Herrero, C. (1999). Chemometric classification of honeys according to their type. II. Metal content data. Food Chemistry, 66, 263-268.

Nanda, V., Sarkar, B. C., Sharma, H. K., \& Bawa, A. S. (2003). Physico-chemical properties and estimation of mineral content in honey produced from different plants in Northern India. Journal of Food Composition and Analysis, 16, 613-619.

Official Methods of Analysis of AOAC International (2002) 17th Ed., Rev 1, AOAC International, Gaithersburg, MD, USA, Official Method 991.25. Calcium, magnesium, and phosphorus in cheese-atomic absorption spectrophotometric and colorimetric method.

Pisani, A., Protano, G., \& Riccobono, F. (2008). Minor and trace elements in different honey types produced in Siena County (Italy). Food Chemistry, 107, 1553-1560.

Rashed, M. N., \& Soltan, M. E. (2004). Major and trace elements in different types of Egyptian mono-floral and nonfloral bee honeys. Journal of Food Composition and Analysis, 17, 725-735.

Souci, S. W., Fachmann, H., \& Kraut, H. (2002). Food composition and nutrition tables. Stuttgart: Medpharm Scientific.

Szefer, P. (2007). Chemometric techniques in analytical evaluation of food quality. In P. Szefer \& J. O. Nriagu (Eds.), Mineral components in foods (pp. 69-122). London: CRC, Taylor Francis Group.

Szefer, P., \& Grembecka, M. (2007). Mineral components in foods of animal origin and in honey. In P. Szefer \& J. O. Nriagu (Eds.), Mineral components in foods (pp. 163-230). London: CRC, Taylor Francis Group.

Terrab, A., González, A. G., Díez, M. J., \& Heredia, F. J. (2003). Mineral content and electrical conductivity of the honeys produced in Northwest Morocco and their 
contribution to the characterization of unifloral honeys. Journal of the Science of Food and Agriculture, 83, 637-643.

Terrab, A., Recamales, A. F., Hernanz, D., \& Heredia, F. J. (2004). Characterisation of Spanish thyme honeys by their physicochemical characteristics and mineral contents. Food Chemistry, 88, 537-542.

Tuzen, M., Silici, S., Mendil, D., \& Soylak, M. (2007). Trace element levels in honeys from different regions of Turkey. Food Chemistry, 103, 325-330.

WHO. 72nd Meeting of the Joint FAO/WHO Expert Committee on Food Additives. Rome, 16-25 February 2010a. http:// www.who.int/foodsafety/chem/summary72_rev.pdf accessed 25th April 2010

WHO. 73rd Meeting of the Joint FAO/WHO Expert Committee on Food Additives. Geneva, 8-17 June 2010b. http:// www.who.int/foodsafety/publications/chem/summary73.pdf accessed 25th April 2010

Xu, Y., Luo, L., Chen, B., \& Fu, F. (2009). Recent development of chemical components in propolis. Frontiers of Biology in China, 4, 385-391.

Yilmaz, H., \& Yavuz, O. (1999). Content of some trace metals in honey from south-eastern Anatolia. Food Chemistry, 65, 475-476. 